\title{
Effect of Repeated Magnetization Process of Water on the Waterand Soil Properties as well as Lettuce Yield
}

Walaa A. Abd-Elrahman, Harby Mostafa and Adel Bahnasawy

Agric. and Biosys. Eng. Dept., Faculty of Agric., Benha Univ., Moshtohor, Toukh, Qalyobia, Egypt.

Corresponding author: waLaaahmed092@gmail.com

\begin{abstract}
It is known that the magnetic field works to change the chemical and physical properties of water and this is reflected in the properties of soil and plant. An experiment was conducted during 2017 and 2018 seasons at a farm in MitKenana village, Qalyobia, Egypt. The aim was to study the effect of water re-magnetization on the properties of water, soil and Lettuce growth. The experiment was divided into four treatments with three replicates. Normal water treatment and other magnetized water treatments were irrigated with water passed through the magnetic device one, two and three times. EC, pH, anions and cations for both water and soil as well as yield and yield components for Lettuce were measured. Results indicated that, irrigation with magnetized water induced positive significant effect on all studied treatments on water, soil and plant where it improved water and soil properties with increasing plant productivity. The one-time passing magnetic treatment of irrigation water significantly decreased electrical conductivity of the soil, but the effect on $\mathrm{pH}$ was moderatein addition to increasing lettuce productivity by $29.1 \%$ more than non-magnetic treatment. With multiple magnetic treatments, did not show big differences between treated and untreated treatments.
\end{abstract}

Keywords: magnetized water, soil, lettuce yield.

\section{Introduction}

The agricultural production is one of the most important elements contributing to national income and food security, so it can be increased through horizontal or vertical expansion. May be there is no opportunity for horizontal expansion, so vertical expansion is the best solution by following various scientific methods in using water of poor quality and/or management of soil and crop service operations, and from these methods, the use of magnetic technology.

The use of magnets was not modern it has been used since long-time ago. It was used by the Pharaohs, Chinese, Greeks and Indians in medicine, industry and various fields. As a result of the development of magnetic science, it emerged that the magnetic properties are not confined to iron, nickel and manganese, but are a property that is related to all solid, liquid, gaseous and all organisms (Hilal, 2005).Different schools have also emerged, according to their use for the type of magnet or the purpose of its use, some of which uses the system of one pole North or Antarctica, and other uses the poles. Magnetized water is known as water passing through magnets and the degree of water treatment magnetically depends on three factors (Ahmed, 2009): the amount of fluid in the magnetic device, the strength of the magnet used for this purpose and duration of treatment. Magnetic water treatment works to strengthen water properties by positively regulating negative, negative, and negative charges. When the molecules of water are placed in a magnetic field, the hydrogen bonds between the molecules either change or disintegrate and reduce the angle of the adhesion to less than $105^{\circ}$ (Hilal and Hilal, 2000), which reduces the level of union between the molecules, thus absorbing the energy. Among them, increases the susceptibility of electrolysis, and affects the decomposition of crystals.

Magnetized water leads to break down large crystals into small crystals, easily passing through the roots of plant and soil pores. Therefore, the amount of salts in the water is the same as the ratio that is not less, but not harmful, because the plant will take all that needs to grow, and the rest of the crystals of salts and other components useless can be leached easily from soil (Hassan et al., 2005). The seeds processed magnetically grow rapidly and give better results and have higher productivity and a more developed and developed root system (Fairgrieve, 2011). Existence of salts in water and soil is a very serious problem. Therefore, looking for an effective solution for this problem is the use of magnetic field to affect the properties of soil and water as well as affect the growth and productivity of plants. So, the main aim of this work is to use the magnetized water in producing the lettuce plant improve soil and water properties.

\section{Material and Methods}

An experiment was conducted on a farm in MitKenana village, Qalyobia, Egypt during 2017 । 2018 seasonsto study the effect of water remagnetization (one, two and three times) on water and soil properties and crop productivity. Physical and chemical properties of soil and chemical properties of water are shown in Table (1) and Table (2) 
Table 1. Chemical analysis of water at experimental site.

\begin{tabular}{|c|c|c|c|c|c|c|c|c|c|}
\hline \multicolumn{10}{|c|}{ Chemical properties } \\
\hline \multirow{2}{*}{ pH } & \multirow{2}{*}{$\begin{array}{l}\mathrm{EC} \\
\left(\mathrm{dSm}^{-1}\right)^{*}\end{array}$} & \multicolumn{3}{|c|}{ Soluble cations $\left(\mathrm{mmol}_{\mathrm{C}} \mathrm{L}^{-1}\right)$} & \multicolumn{5}{|c|}{ Soluble anions $\left(\mathrm{mmol}_{\mathrm{C}} \mathrm{L}^{-1}\right)$} \\
\hline & & $\mathrm{Ca}^{2+}$ & $\mathrm{Mg}^{2+}$ & $\mathrm{Na}^{+}$ & $\mathbf{K}^{+}$ & $\mathrm{Cl}^{-}$ & $\mathrm{CO}_{3}=$ & $\mathrm{HCO}_{3}^{-}$ & $\mathrm{SO}_{4}=$ \\
\hline 7.53 & 1.57 & 2.10 & 2.40 & 3.22 & 0.80 & 1.50 & 0.00 & 2.60 & 4.42 \\
\hline
\end{tabular}

${ }^{*} \mathrm{dSm}{ }^{-1}=640 \mathrm{ppm}$

Table 2. Physical and chemical analysis of the soil

\begin{tabular}{|c|c|c|c|c|c|c|c|c|c|c|}
\hline \multicolumn{11}{|c|}{ Physical properties } \\
\hline \multicolumn{2}{|c|}{ Depth (cm) } & \multicolumn{2}{|c|}{ Sand $(\%)$} & \multicolumn{2}{|c|}{ Silt (\%) } & & \multicolumn{2}{|c|}{ Clay $(\%)$} & \multicolumn{2}{|c|}{ TexturalClass } \\
\hline \multicolumn{2}{|l|}{$0-40$} & \multicolumn{2}{|c|}{$81.5 \%$} & \multicolumn{2}{|c|}{$13.5 \%$} & & $5 \%$ & \multicolumn{2}{|r|}{ Sand } & \\
\hline \multicolumn{11}{|c|}{ Chemical properties } \\
\hline \multirow{2}{*}{$\begin{array}{l}\text { Depth } \\
\text { (cm) }\end{array}$} & \multirow{2}{*}{ pH } & \multirow{2}{*}{$\begin{array}{l}\text { EC } \\
\mathrm{dSm}^{-1}\end{array}$} & \multicolumn{4}{|c|}{ Soluble cations $\left(\mathrm{mmolc}_{\mathrm{c}} \mathbf{L}^{-1}\right)$} & \multicolumn{4}{|c|}{ Soluble anions $\left(\operatorname{mmol}_{\mathbf{c}} \mathbf{L}^{-1}\right)$} \\
\hline & & & $\mathrm{Ca}^{2+}$ & $\mathrm{Mg}^{2+}$ & $\mathrm{Na}^{+}$ & $\mathbf{K}^{+}$ & $\mathbf{C l}^{-}$ & $\mathrm{CO}_{3}=$ & $\mathrm{HCO}_{3}^{-}$ & $\mathrm{SO}_{4}=$ \\
\hline $0-20$ & 7.85 & 1.1 & 2.10 & 2.40 & 3.22 & 0.80 & 4 & 0.00 & 1.4 & 5.6 \\
\hline $20-40$ & 7.87 & 0.95 & 1.1 & 2.2 & 5.5 & 0.2 & 3 & 0.00 & 1.4 & 6 \\
\hline $40-60$ & 7.83 & 0.82 & 2.1 & 1 & 4.7 & 0.2 & 3.5 & 0.00 & 1.4 & 3.1 \\
\hline
\end{tabular}

\section{Magnetic Device}

A permanent magnet with a magnetic strength of 1600 Gauss was used in this study formagnetizing irrigation waters. The set up of the unit for the magnetic treatment of irrigation water is shown in Fig (1).The magnetic device ( $40 \mathrm{~cm}$ long) consists of an internal metal tube (25 mm diameter) and an external stainless steel tube (52 $\mathrm{mm}$ diameter) and the magnets are among, where the direction of current is vertical with the passage level of the material.The device can be easily installed through the pipe network as shown in Fig (2).

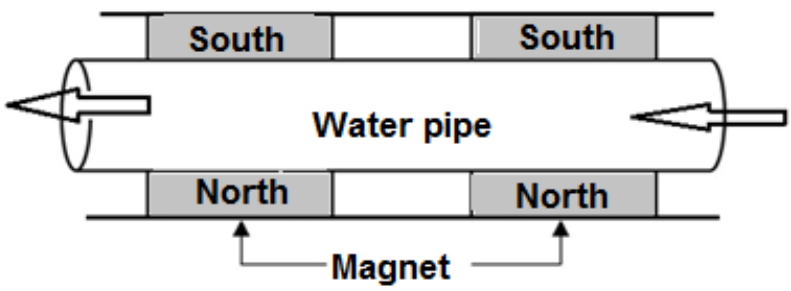

Fig. 1: The magnetic device

\section{Experimental Design:}

A PVC beaker of 100 liter capacity fitted at the top of the unit served as the storage tank for the untreated water. Water from the bottom of this tank enters the magnetic device. For the magnetic treatment of irrigation water, it was passed through the magnetic treatment device providing the water a magnetic field exposure of about $6 \mathrm{~S}$ (Gudigar, 2013) to use for irrigation or collected in another PVC tank after the device.

The experiment is divided into four treatments as shown in Fig (2):

The first treatment: used normal water (non-magnetic water) as a control.

The second treatment: water passed through the device once, where water is taken directly from the device to use for irrigation.

The third treatment: water passed through the device twice, where water that magnetized once is collected in a PVC tank set after the device and back again to the device for re-magnetization (two times passed) and use for irrigation.

The fourth treatment: water passed through the device three times, where water that magnetized twice is collected in the PVC tank set after the device and back again to the device for re-magnetization (three times passed) and use for irrigation.

Lettuce plants from local market were transplanted in each treatment and irrigated as scheduled by magnetic and non-magnetic water.

Water and soil characteristics were measured in Soil Fertility Lab - Plant Nutrition Research Department - Soil, Water and Environment Research Institute, Ministry of Agriculture, Egypt.

Soil pH (pH meter: JENCO 1671 Model, USA, with 0.1 accuracy)and EC (EC Meter: ORION 105 Model, USA, 0 to $199.99 \mathrm{dS} \mathrm{m}^{-1}$, and $0.5 \% \mathrm{~F} \mathrm{~S}$ accuracy)were measured in 1:2.5 soil, water suspensions in soil paste extract, respectively. Some soluble cations and anions were determined by titration methods and flame photometer (Jenway PFP7 Model, USA) according to Jackson (1967).

Drip Irrigation System:

The components of the drip irrigation network were as follows:-

1. Drum with 100 liters capacity, fill with normal water as a water source for providing the 
magnetic device and irrigate the non-magnetized treatment.

2. P.E pipe lines of $50 \mathrm{~mm}$ diameter were used to convey and distribute irrigation water from the source to the supply laterals (drip lines).
3. P.E laterals of $16 \mathrm{~mm}$ diameter with built-in drippers (4 L/h/30cm spacing) and $75 \mathrm{~cm}$ between lines.

4. 20 liter plastic kits were used as fertilizer tank.

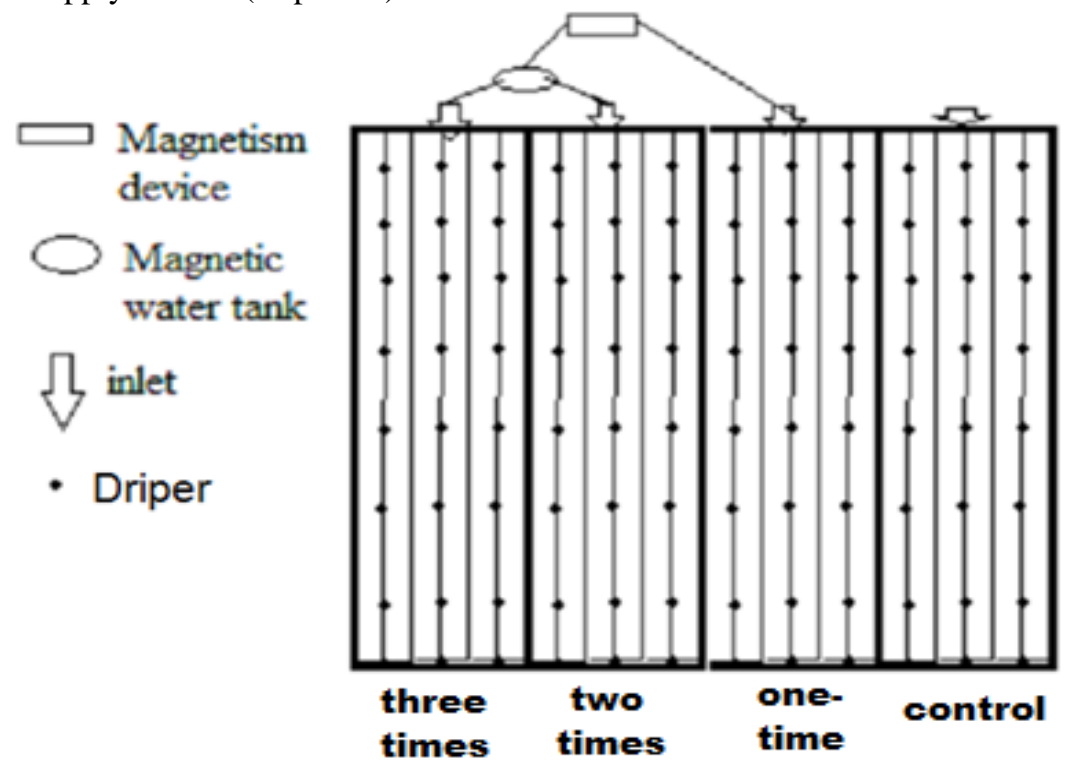

Fig. 2: Experimental layout

\section{Growth Parameters:}

In the lettuce, the measurements were taken at the end of the season.The following characteristics were measured: plant length $(\mathrm{cm})$, number of leaves, chlorophyll ratio, head diameter $(\mathrm{cm})$, fresh and dry weight of shoot $(\mathrm{g})$, fresh and dry weight of roots $(\mathrm{g})$ and yield.

\section{Results and Discussion}

This experiment was done to study the effect of the repeated magnetization process of irrigation water on water properties such as (EC, $\mathrm{pH}$,ions and cations), soil properties (EC, $\mathrm{pH}$, ions and cautions) and lettuce plant characterization (vegetable, root parameters and productivity).

\section{Effect of Repeated Magnetization Process on Water Properties \\ $1.1 \mathrm{pH}$ of water}

Data in Table (3) shows the $\mathrm{pH}$ after the magnetization process compared to the normal water.
The results indicate that values of waterpHincreased after exposing to the magnetic field and by repeating the process of magnetism. The values were 7.53, 7.81, 7.83 and 7.87 for normal water, the magnetization one, two and three times. This increase in $\mathrm{pH}$ when the magnetization process is repeated due to the formation of more ions of bicarbonate, calcium, hydroxide and alkaline substances which reduced the acidity as decided byHassani et al. (2015).

\subsection{EC of water}

EC of water after the magnetization process compared to the control is shown in Table (3). EC was increased for magnetization once $\left(2.06 \mathrm{dSm}^{-1}\right)$ and twice $\left(2.8 \mathrm{dSm}^{-1}\right)$ while there was no more increasing for the thrice $\left(2.8 \mathrm{dSm}^{-1}\right)$ compared with the normal water $\left(1.57 \mathrm{dSm}^{-1}\right)$. It is clear that the increase in EC may be due to low entropy in saline samples and this leads to rearrangement of the molecules as reported by Ibrahim et al. (2013). This is due to the decrease of entropy to strengthen the hydrogen bondsbecause of magnetization process.

Table 3. Effect of repeated magnetization process on water properties

\begin{tabular}{|c|c|c|c|c|c|c|c|c|c|}
\hline \multirow[b]{2}{*}{ Treatment } & \multirow{2}{*}{$\mathbf{p H}$} & \multirow{2}{*}{$\begin{array}{c}\mathrm{EC} \\
\left(\mathrm{dSm}^{-1}\right)\end{array}$} & \multicolumn{4}{|c|}{ Soluble cations $\left(\mathrm{mmol}_{\mathrm{C}} \mathrm{L}^{-1}\right)$} & \multicolumn{3}{|c|}{ Soluble anions $\left(\mathrm{mmol}_{\mathbf{C}} \mathbf{L}^{-1}\right)$} \\
\hline & & & $\mathrm{Ca}^{2+}$ & $\mathrm{Mg}^{2+}$ & $\mathrm{Na}^{+}$ & $\mathbf{K}^{+}$ & $\mathrm{Cl}^{-}$ & $\mathrm{HCO}_{3}^{-}$ & $\mathrm{SO}_{4}=$ \\
\hline Control & 7.53 & 1.57 & 5.1 & 3.6 & 6.3 & 0.3 & 4.9 & 4 & 6 \\
\hline One time passed & 7.81 & 2.06 & 5.9 & 3.8 & 5.9 & 0.6 & 7.2 & 5 & 7.8 \\
\hline Two times passed & 7.83 & 2.08 & 5.7 & 3.0 & 8.4 & 0.8 & 8 & 4 & 8 \\
\hline Three times passed & 7.87 & 2.08 & 3.7 & 2.9 & 10.1 & 1.3 & 10.2 & 1.9 & 8.3 \\
\hline
\end{tabular}




\subsection{Anions and cations}

Among magnetic water, passing water once through the magnetic device, calcium and magnesium content increased over normal water (Table 3). With subsequent multiple magnetic treatments (two and three times passed), calcium and magnesium content though decreased numerically. Potassium content increased from 0.3 to $0.6 \mathrm{mmol}_{\mathrm{C}} \mathrm{L}^{-1}$, while sodium content decreased from 6.3 to $5.9 \mathrm{mmol}_{\mathrm{C}} \mathrm{L}^{-1}$ for passing water once through the magnetic device. With subsequent multiple magnetic treatments (two and three times passed), Potassium and sodium content, though increased numerically. This may be due to the slowing down effect of mineral ions due to crystallization and precipitation processes induced by the magnetic treatment. A similar result was reported by Gudigar (2013).

\section{Effect of Repeated Water Magnetization Process on Soil Properties \\ $2.1 \mathrm{pH}$ of soil}

The results clarified that the soil $\mathrm{pH}$ is decreased at the end of growing season by using magnetized water treatments as shown in Table (4) for all soil depths. The soil $\mathrm{pH}$ was slightly negatively influenced by magnetic treatments (one, two and three times passed), where it decreased by an average of 0.08 , 0.11 , and 0.06 for $0-20,20-40$ and $40-60 \mathrm{~cm}$ depths, respectively. There was no effect of the magnetic process repetition.

The average $\mathrm{pH}$ value was lower (7.77) for magnetic treatments than that of the untreated treatment (7.85). The reduction in soil $\mathrm{pH}$ may be due to the effect of magnetic field on organic matter in the soil where it releases relatively greater of organic acids in rhizosphere as deduced by Maheshwari and Grewal 2009, and Al Khazan et al. 2011.

Table 4. Effect of repeated water magnetization process on $\mathrm{pH}$ and Ec of soil.

\begin{tabular}{cccccc}
\hline \multirow{2}{*}{ Treatment } & \multirow{2}{*}{$\begin{array}{c}\text { Depth } \\
(\mathbf{c m})\end{array}$} & $\begin{array}{c}\text { Non- } \\
\text { magnetic }\end{array}$ & One time passed & Two times passed & $\begin{array}{c}\text { Three times } \\
\text { passed }\end{array}$ \\
\cline { 3 - 6 } & $0-20$ & 7.85 & 7.77 & 7.78 & 7.77 \\
$\mathrm{pH}$ & $20-40$ & 7.87 & 7.75 & 7.76 & 7.76 \\
& $40-60$ & 7.83 & 7.76 & 7.77 & 7.77 \\
$\mathbf{E C}$ & $0-20$ & 1.15 & 0.75 & 0.87 & 0.86 \\
$\left(\mathbf{d S m}^{-1}\right)$ & $20-40$ & 1.12 & 0.77 & 0.88 & 0.87 \\
& $40-60$ & 1.11 & 0.74 & 0.85 & 0.85 \\
\hline
\end{tabular}

\subsection{EC of soil}

There was a decrease in EC of soil solution where the values decreased from $1.15,1.12$ and $1.11 \mathrm{dSm}^{-1}$ at the beginning of the growing season to $0.75,0.77$ and $0.74 \mathrm{dSm}^{-1}$ at the end of the growing season with using one time passed magnetic water for 0-20, 20-40 and $40-60 \mathrm{~cm}$ depths, respectively. Also, there was a decrease in EC of soil solution in case of two and three times passed magnetic water, but less than one time passed magnetic water as shown in table (4). These results reveal that the irrigation with magnetic water can be considered as one of the most valuable modern technique that can help in reducing salt accumulation in soils and improve soil conditions around plant roots especially with using one time passed magnetic water in our case.

These results may be attributed to that the dissolving properties of water increase when started with the magnetic field as the magnetic water has small molecules, less viscosity, faster water movement and permeability at soil pores as cleared by Al Khazanet al. (2011). Total salts removal from soil with magnetic water was greater than normal water.
Magnetic water removes the excess of soluble salts and leaches the salts for away than the root zone (Hilalet al., 2012 and Abou El Yaziedet al., 2012).

\subsection{Anions and cations of soil}

In respect of the essential elements for plants, i.e. $\mathrm{Ca}, \mathrm{Mg}, \mathrm{K}$ and $\mathrm{Na}$, the results in Table (5) revealed that magnetic water affected the solubility of these elements in the soil. The mean value of soluble contents for the three depths of these elements is changed from $2.3,1.7,0.5$ and $5.8 \mathrm{mmol}_{\mathrm{C}} \mathrm{L}^{-1}$ before cultivation to $2.03,1.2,0.35$ and 3.2 mmol $_{\mathrm{C}} \mathrm{L}^{-1}$ at the end of the growing season for $\mathrm{Ca}, \mathrm{Mg}, \mathrm{K}$ and $\mathrm{Na}$, respectively for one time passed magnetic water. This is clear that the solubility of these elements is decreased by $11.7,29.4,30$ and $51 \%$, respectively, meanwhile the decrease when using two times passed were 4.3, 29.4, 22 and $46.1 \%$, and when using three times passed were 4.8, 17.6, 20 and $45 \%$ for $\mathrm{Ca}, \mathrm{Mg}$, $\mathrm{K}$ and $\mathrm{Na}$, respectively. It appears that magnetic water lead to intensive reduction of soluble Na salts $(>45 \%$, meanwhile the decrease of other elements $(\mathrm{Ca}, \mathrm{Mg}$ and $\mathrm{K}$ ) was less than $30 \%$. 
Table 5. Effect of repeated water magnetization process on chemical properties of soil.

\begin{tabular}{|c|c|c|c|c|c|c|c|c|}
\hline \multirow{3}{*}{ Treatment } & \multicolumn{8}{|c|}{ Chemical properties } \\
\hline & \multirow{2}{*}{$\begin{array}{c}\text { Depth } \\
\text { (cm) }\end{array}$} & \multicolumn{4}{|c|}{ Soluble cations $\left(\mathrm{mmolc}_{\mathrm{C}} \mathrm{L}^{-1}\right)$} & \multicolumn{3}{|c|}{ Soluble anions $\left(\right.$ mmolc $\left._{\mathbf{c}} \mathbf{L}^{-1}\right)$} \\
\hline & & $\mathrm{Ca}^{2+}$ & $\mathrm{Mg}^{2+}$ & $\mathrm{Na}^{+}$ & $\mathbf{K}^{+}$ & $\mathrm{Cl}^{-}$ & $\mathrm{HCO}_{3}{ }^{-}$ & $\mathrm{SO}_{4}=$ \\
\hline \multirow{3}{*}{$\begin{array}{l}\text { Normal } \\
\text { Water }\end{array}$} & $0-20$ & 2.5 & 1.5 & 6.3 & 0.5 & 4.0 & 1.4 & 5.6 \\
\hline & $20-40$ & 2.2 & 1.4 & 6.5 & 0.5 & 3.1 & 1.4 & 6.0 \\
\hline & $40-60$ & 2.2 & 2.2 & 6.7 & 0.5 & 3.5 & 1.4 & 3.1 \\
\hline \multirow{3}{*}{ One time passed } & $0-20$ & 2.1 & 0.8 & 3.3 & 0.36 & 3.0 & 1.5 & 2.5 \\
\hline & $20-40$ & 1.9 & 1.5 & 3.0 & 0.34 & 3.1 & 1.0 & 3.9 \\
\hline & $40-60$ & 2.1 & 1.3 & 3.3 & 0.35 & 3.2 & 1.5 & 3.0 \\
\hline \multirow{3}{*}{$\begin{array}{l}\text { Two times } \\
\text { passed }\end{array}$} & $0-20$ & 2.2 & 1.1 & 3.6 & 0.36 & 3.1 & 1.3 & 3.2 \\
\hline & $20-40$ & 2.3 & 1.3 & 3.8 & 0.39 & 3.2 & 1.2 & 3.0 \\
\hline & $40-60$ & 2.2 & 1.2 & 3.1 & 0.36 & 3.1 & 1.3 & 3.2 \\
\hline \multirow{3}{*}{$\begin{array}{l}\text { Three times } \\
\text { passed }\end{array}$} & $0-20$ & 2.2 & 1.3 & 3.6 & 0.5 & 3.2 & 1.2 & 3.1 \\
\hline & $20-40$ & 2.2 & 1.6 & 3.5 & 0.4 & 3.1 & 1.4 & 3.3 \\
\hline & $40-60$ & 2.1 & 1.3 & 3.7 & 0.4 & 3.3 & 1.2 & 3.0 \\
\hline
\end{tabular}

Magnetic water leads to a decrease in sodium content more than other elements in soil solution. This is because $\mathrm{Na}$ is a paramagnetic element which has a small positive susceptibility to magnetic fields, while other elements are diamagnetic which are slightly repelled by a magnetic field as reported by Nave (2008). Maheshwari and Grewal (2009) and Hilal et al. (2012) recorded an increase of $\mathrm{Ca}, \mathrm{Mg}, \mathrm{K}$ concentration into plants that means a decrease of them in the soil.

Soluble anions are decreased with the same rate as cations at the end of the growing season. According to Kronenberg(2011), in non-magnetic water, some of carbonates are deposited in soil pores and on the plant roots, but using magnetic water, carbonate salts cannot precipitate. As well as, it can break down the precipitated salts on internal surface of irrigation pipes and laterals, thus the movement of water will be much easier than non-magnetic water.

\section{Effect of Repeated Water Magnetization Process on Vegetative Growth and LettuceYield}

\subsection{Vegetative growth}

The effect of irrigation using magnetized water on the vegetative growth of plants compared to irrigation using non-magnetic water was studied during two consecutive seasons.

Plant height increases with all magnetized water repetition during both seasons, with the largest increase in length of $38 \mathrm{~cm}$ in the case of one time passed, followed by 37.2 and $31.7 \mathrm{~cm}$ for two and three times passed, respectively, compared to $24.3 \mathrm{~cm}$ in the case of non-magnetic water as shown in Fig (3), this finding agrees with the findings of several researchers as Hozien (2014) and Gudigar (2013).

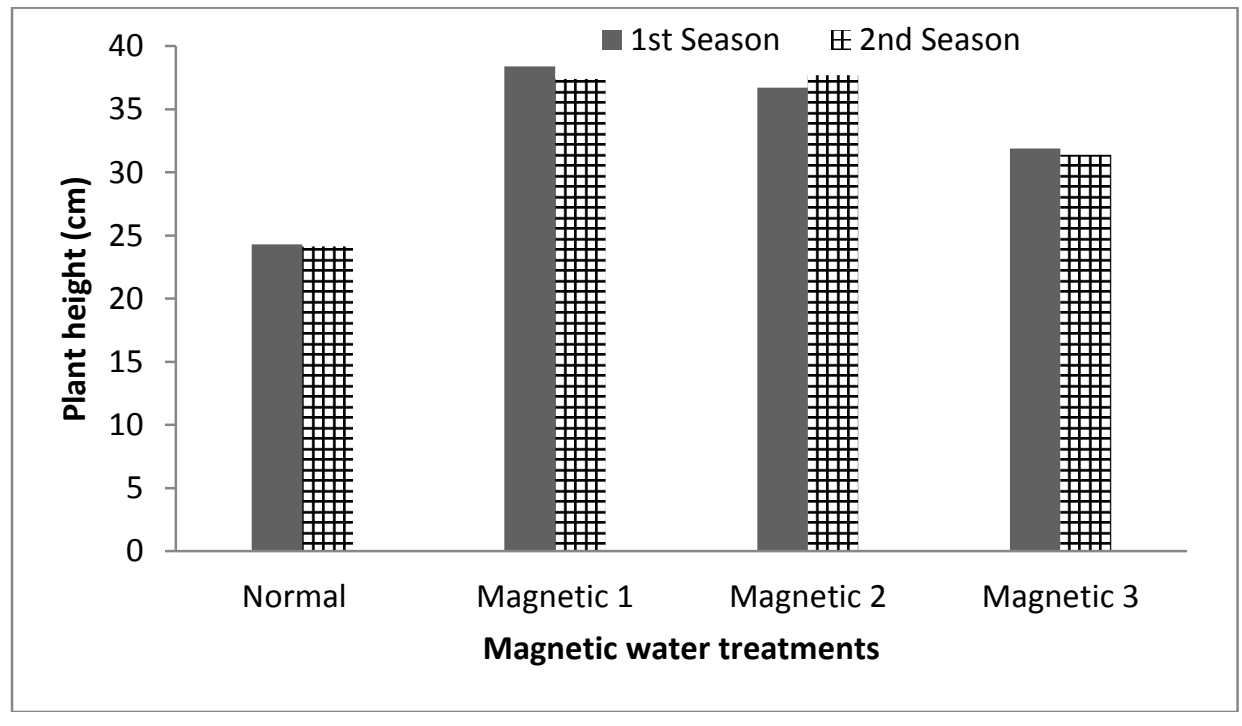

Figure 3. Effect of magnetic water on lettuceplant heightfor two consecutive seasons.

In Fig (4), the effect of magnetized water on the plant diameter is shown clearly where the plant diameter increased with all magnetized water treatments during both seasons, with $26.3 \%, 15.6$ and $2.5 \%$ more 
increase in diameter in the case of one, two and three times passed of water than non-magnetic water. These results are similar to those obtained by Yousif (2017). The increase in plant height and diameter is due to the stimulatory effect of magnetic water may be attributed to their role in increasing absorption and assimilation of nutrients consequently increasing plant growth (Hozien, 2014).

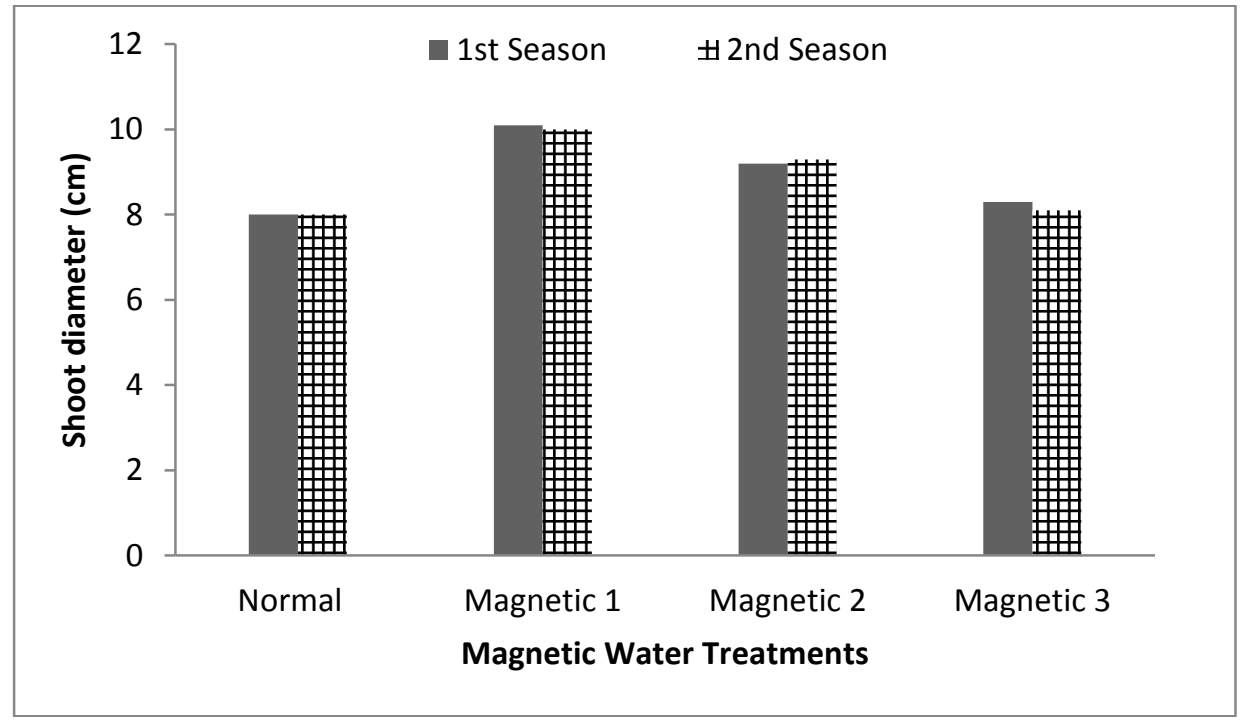

Figure 4. Effect of magnetic water on lettuce plant diameter for two consecutive seasons.

The use of magnetic water in irrigation also affects the appearance of the plant, which can be observed from the leavesnumber and the chlorophyll ratio as shown in Figs (5 and 6).

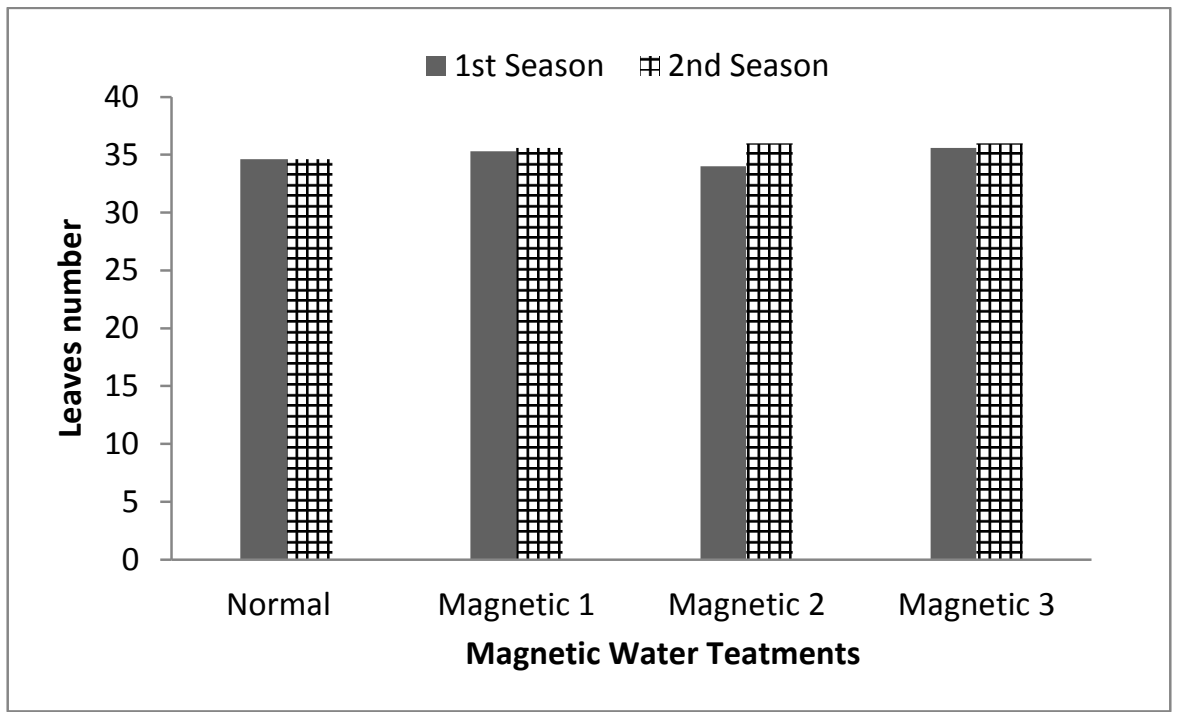

Figure 5. Effect of magnetic water on leaves number of lettuce for two consecutive seasons.

The magnetized water processes affected positively on the average number of plant leaves during both seasons, also the chlorophyll ratio is increased with all magnetized water treatments during both seasons, with the average increase of $8,1.3$ and 0.4 for one, two and three times passed, respectively, compared to in the case of non-magnetic water. The increase of magnetic intensity may discourage the chlorophyll level (in case of two and three times passed)as reported by Gudigar (2013) "there is an increase in chlorophyll ratio when increasing the magnetic field up to a certain limit up to more than 100 leads to discourage the chlorophyll level". 


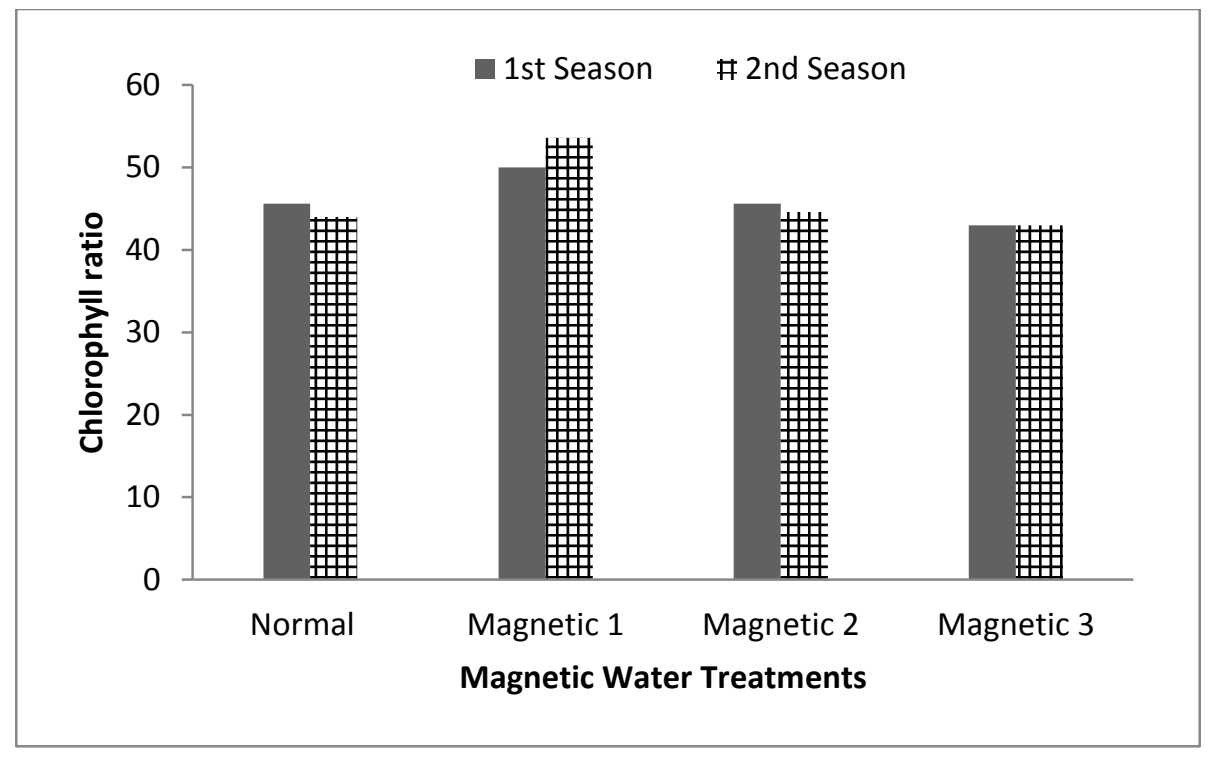

Figure 6. Effect of magnetic water on plant chlorophyll ratio of lettuce for two consecutive seasons.

\subsection{Root growth}

Table (6) shows that results of the root growth took the same trend as the vegetative growth where the values of root length and diameter were higher in one time passed magnetic water $(14.5 \mathrm{~cm}$ and $2.5 \mathrm{~cm})$ followed by two times passed $(13.1 \mathrm{~cm}$ and $2.2 \mathrm{~cm}$ ) compared with non-magnetic $(13.3 \mathrm{~cm}$ and $2 \mathrm{~cm})$, while the value of three times passed magnetized water decreased $(11.1 \mathrm{~cm}$ and $1.7 \mathrm{~cm})$. Fresh and dry root weight gave alike trend, where the average weight was (49.6 and $18.9 \mathrm{~g}$ ) for one time passed, then (48.9 and $16.9 \mathrm{~g}$ ) for twice times passed compared with nonmagnetic (45.9 and $15.5 \mathrm{~g}$ ) and the lowest value was magnetic water for three times that reached (45.1 and $14.4 \mathrm{~g}$ ) for fresh and dry root weight, respectively.

Table 6. Mean values of root length, diameter and fresh and dry weight of lettuce as affected by magnetic water process.

\begin{tabular}{lcccc}
\hline \multirow{2}{*}{ Treatments } & \multicolumn{4}{c}{ Magnetic treatments } \\
\cline { 2 - 5 } & Non-magnetic & One time passed & Two times passed & Three times passed \\
\hline Root length $(\mathrm{cm})$ & 13.3 & 14.5 & 13.1 & 11.1 \\
\hline Root diameter $(\mathrm{cm})$ & 2 & 2.5 & 2.2 & 1.7 \\
\hline Fresh weight $(\mathrm{g})$ of roots & 45.9 & 49.6 & 48.9 & 45.1 \\
\hline Dry weight $(\mathrm{g})$ of roots & 15.5 & 18.9 & 16.9 & 14.4 \\
\hline
\end{tabular}

These results were explained by Grewal and Maheshwari (2011), and Yousif(2017) which the moderate magnetism may lead to increase root growth due to decrease the speed of cell cycle in meristem cells in plant roots during the expansion of root hairs. Therefore, the functional activity can increase the size of mitochondria, calcium over-saturation in the cytoplasm and disruptions in different metabolic systems including $\mathrm{Ca} 2+$ homeostasis in root cells. While Over-magnetization leads to negative effects.

\subsection{Effect of magnetized replication on lettuce yield}

Plant weight (fresh and dry) increased with the use of magnetized water for all magnetized water process compared to non-magnetic water as shown in Figs (7 and 8). The average plant weight that irrigated with one time passed magnetic water reached to $786.1 \mathrm{~g}$ fresh weight with $29.1 \%$ more increase than nonmagnetic and $22.7 \%$ more increase for dry weight. In case of two and three times passed magnetic water, the yield increased with $22.4 \%$ and $14.22 \%$ for fresh weight, $9.7 \%$ and $-6.5 \%$ for dry weight, respectively.This is due to the role of magnetized water at irrigation, which leads to increase the growth of plants and thus increase in fresh and dry plant weight. The increase in plant height and diameter is due to the stimulatory effect of magnetic water may be attributed to their role in increasing absorption and assimilation of nutrients consequently increasing plant growth and yield (Hozien, 2014). 


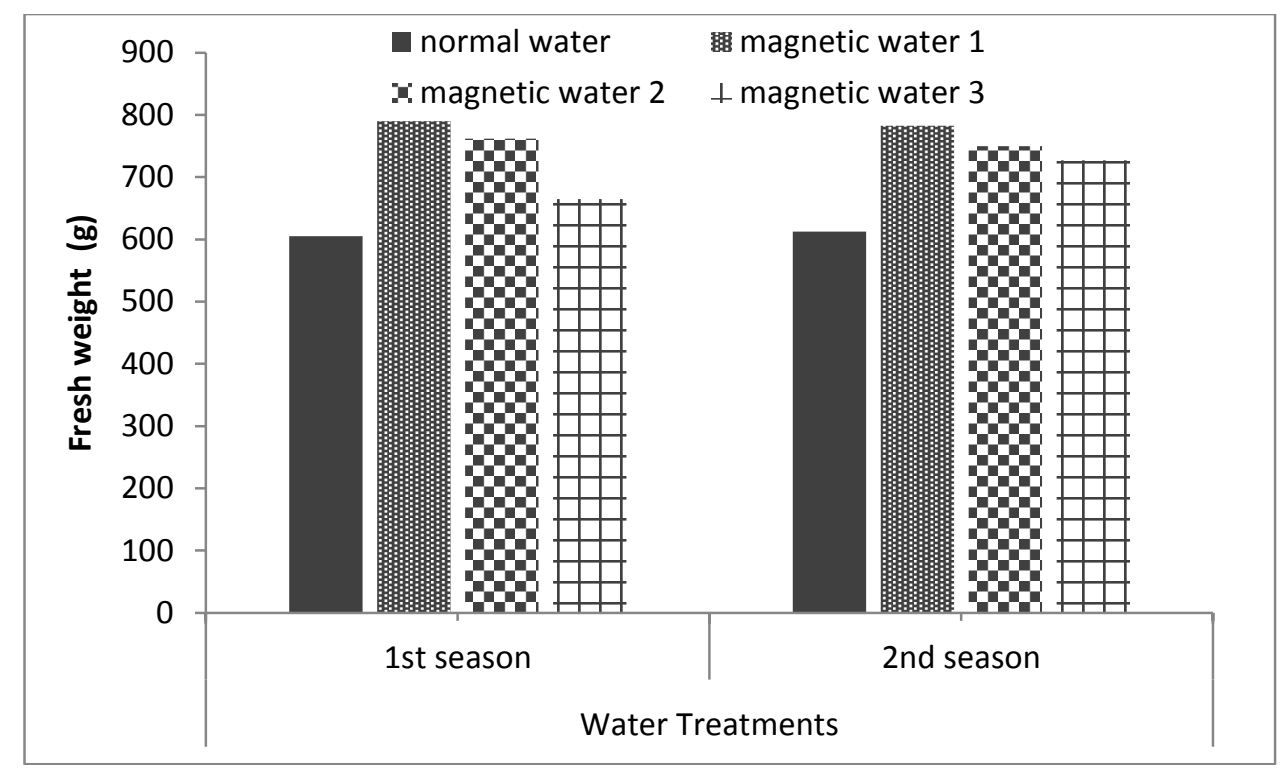

Figure (7): Effect of magnetic water on lettuce fresh weight for two consecutive seasons.

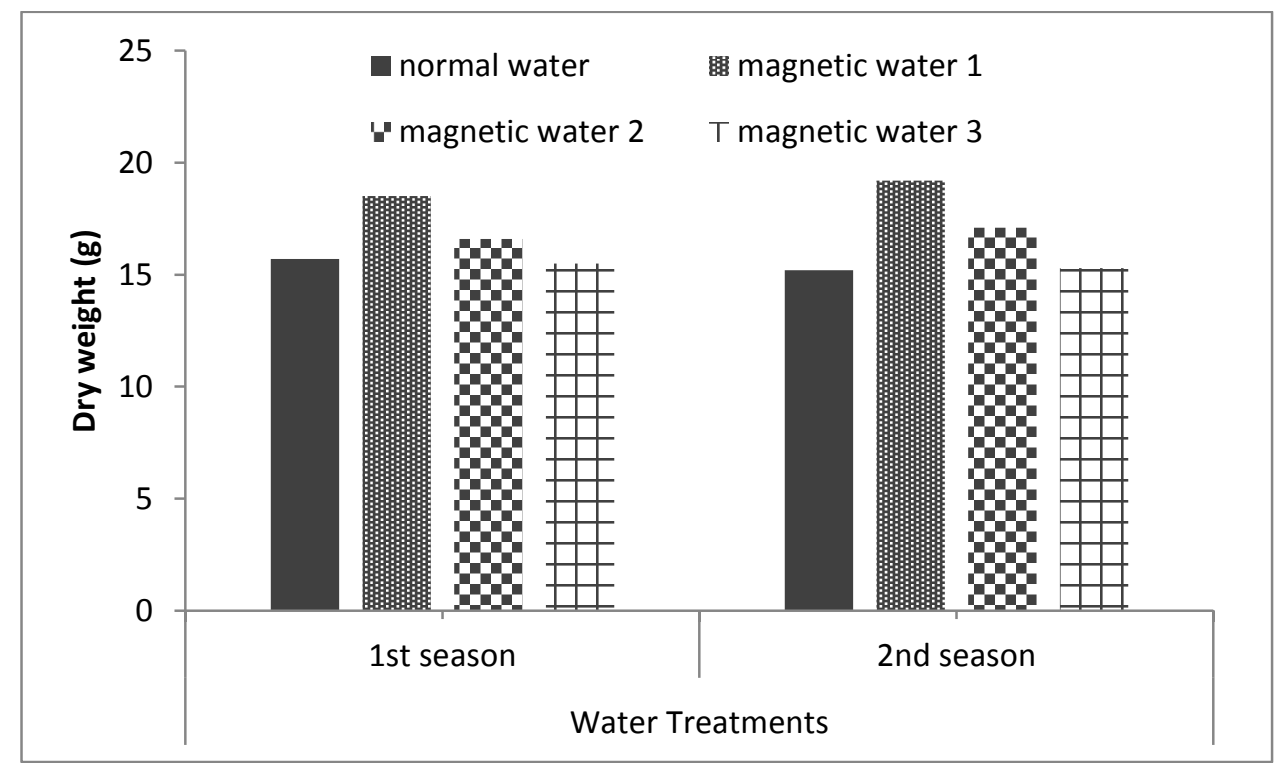

Figure (8): Effect of magnetic water on dry weight of lettuce for two consecutive seasons.

\section{Conclusion}

The above results show that magnetized water once had a greater effect on shoot and root growth and production of lettuce, while there was no significant differences between the magnetic two and three times and the lowest rate was with non-magnetic water.

The results indicated that magnetized water had a positive effect on all studied water, soil and plant treatments and improved water and soil characteristics while increasing plant productivity.

The one-time magnetization of irrigation water led to a decrease in electrical conductivity of the soil, but the effect on $\mathrm{pH}$ was the average decline and plant productivity increased by $29.1 \%$ more than the treatment irrigated with non-magnetized water. With the repetition of the magnetization process, the difference between them and the non-magnetic treatment became increasingly narrow, so that the repetition of magnetization was not helpful in this case.

The process of repeating the magnetization (two and three times passed)may havean advantage of breaking the salts in case of high salinity water, but not recommended in water with low or moderate salt concentration.

\section{References}

Abou El-Yazied, A., El-Gizawy, A. M., Khalf, S. M.and El-Satar, A. (2012). Effect of magnetic field treatments for seeds and irrigation water as well as N, P and $\mathrm{K}$ levels on productivity of tomato plants. J. Applied Sci. Res.,8(4), 2088-2099. 
Ahmed, S.M. (2009). Effect of Magnetic Water on Engineering Properties of concrete. Al-Rafidain Engineering. 17(1): 71-82.

Al-Khazan, M., Abdullatif, B.M. and Al-Assaf , N.(2011) Effect of magnetically treated water on water status, chlorophyl1 pigments and some element content of Jojoba at different growth. African J. of Enviro. Sci. and Tech. 5 (9),722-731.

Fairgrieve, J.D. (2011). Magnetic Treatment of Seeds. Life Streams International Mfg. Co. 5203 Moore Road, Westmoreland, NY 13490 USA. http://www.whollywater.com/magnetizer/plant.htm

Gudigar, A.H. (2013). Effect of magnetic treatment on irrigation water quality, soil properties and growth of sunflower crop.M.Sc. University of Agricultural Sciences, Dharwad.

Hassan, Q.; A. Abd Fahd; A. S. Faleh and T. L. Rashed.(2005 in Arabic).Magnetic Adaptation of Saltwater Properties for Crop Irrigation (Sunflower).Journal of Iraqi Agricultural Sciences. 36 (1): 23-28.

Hassani, S. A.; L. H. Zaid and A. R. Khalid (2015).Experimental Study of the Interaction of Magnetic Fields with Flowing Water, International Journal of Basic and Applied Science, 3(3):1-8.

Hilal, M. H. (2005 in Arabic). Magnetism development - techniques, and utilization in the fields of agriculture, irrigation and environment. Magnetic Technology Corner. A collection of articles on magnetic technology published in the local journal. Dubai, United Arab Emirates. Pp. 43-45.
Hilal, M.H.; and M.M. Hilal.(2000). Application of magnetic technology in desert agriculture.IIEffect of magnetic treatments of irrigation water on salt distribution in olive and citrus field and induced changes of ionic balance in soil and plant. Egypt. J. Soil Sci. 40(3): 423-435.

Hilal, M. H., El-Fakharaniy, Y. M., Mabrouk, S.S., Mohamed, A.I and Ebead, B. M. (2012). Effect of magnetic treated irrigation water on salt removal from a sandy soil and on the availability of certain nutrients. Int. J. of Engineering and App. Sci.

Hozien M. (2014). Opportunetions of magnetic technology applications in Egyptian agriculture Forum.Future of Magnetic Agric. in Egypt,National Res. Cent.

Ibrahim, H. I.; S. Moselhy; J. A. Khan and M. A. Bin Gabous (2013).Modulation of Human Erythrocytes Properties Post Exposed to Static Mag. Field, Life Sci. J., 10 (3):1380-1386.

Jackson, M. L., 1967, Soil Chemical Analysis, Prentice Hall of India, Pvt. Ltd., New Delhi.

Kronenberg, K. J. (2011). Magneto hydrodynamics: The effect of magnets on fluids. GMX International.http://gmxinternational.com/facts/m agneto.htm

Maheshwari, B.L. and Grewal, H. S. (2009) Magnetic treatment of irrigation water: Its effects on vegetable crop yield and water productivity. Agric. Water Manage. 96,1229-1236

Nave, C.L.(2008). Magnetic properties of solids, Hyper Phys., 15,11-23.

Yousif, F. E Imriad (2017).Effect of magnetic water irrigation and some fertilization treatments on head Lettuce. M.Sc. Thesis. Fact.of Agric., Mansoura Univ., Egypt. 
